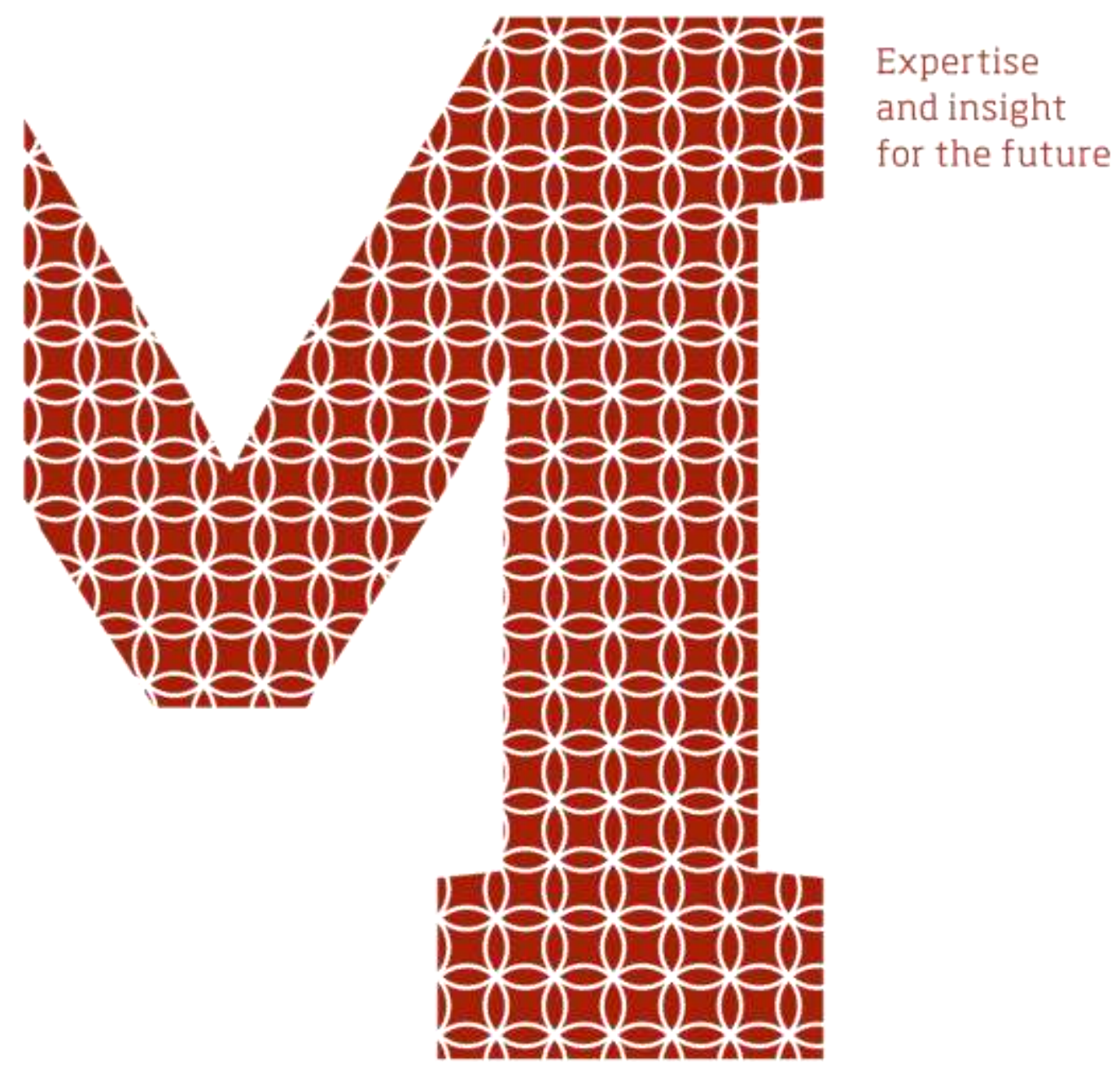

Samir Koirala

\title{
Water Quality Monitoring System
}

Metropolia University of Applied Sciences

Bachelor of Engineering

Degree Programme in Electronics

Bachelor's Thesis

20 December 2020 


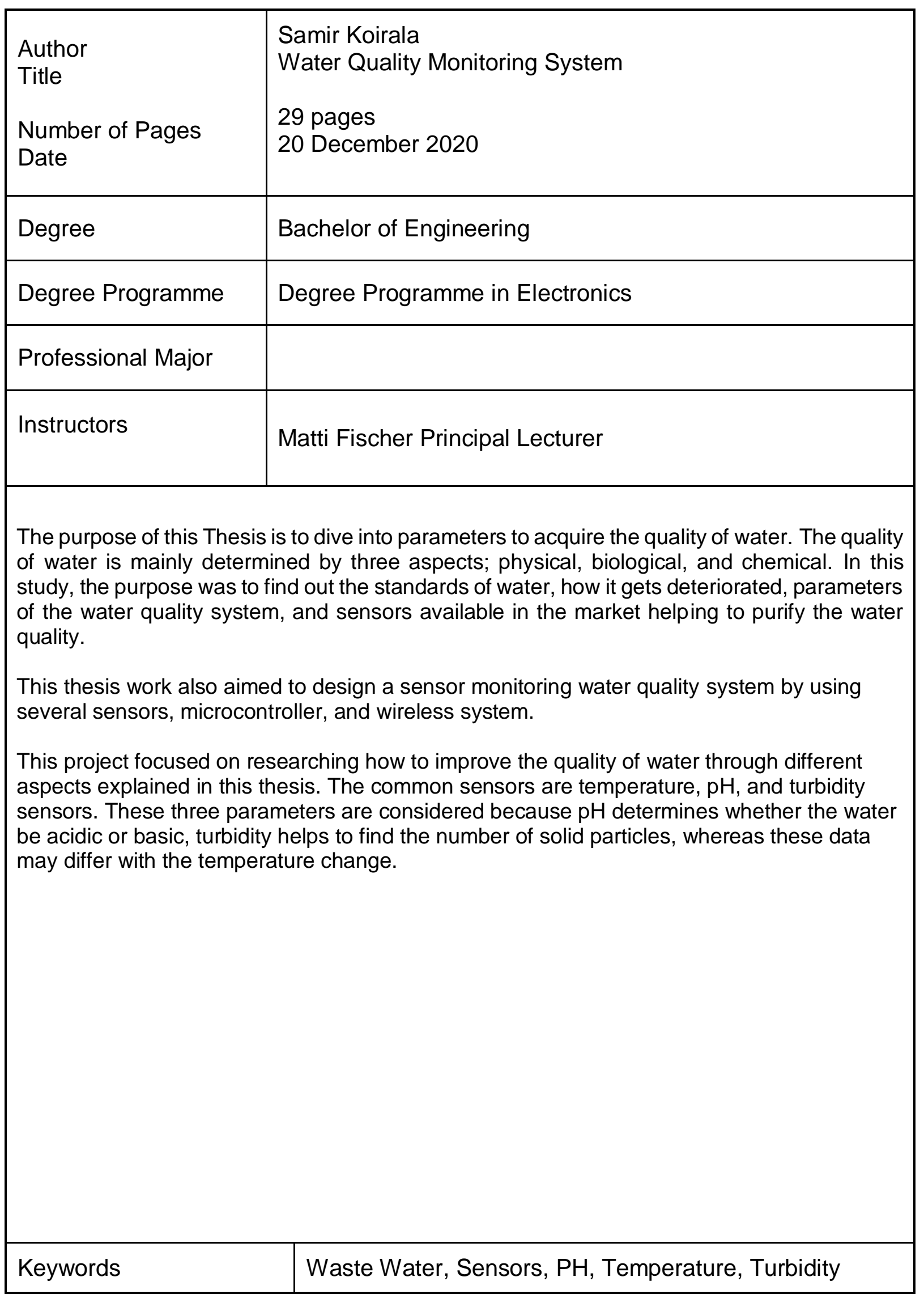




\section{Contents}

List of Abbreviations

1. Introduction

2. Deterioration of Quality of Water 2

2.1 Oxygen-demanding Waste 3

2.2 Pathogenic Organisms 4

2.3 Nutrients 5

2.4 Oil Spills 6

$\begin{array}{ll}\text { 3. Parameters of Water Quality System } & 7\end{array}$

3.1 Temperature $\quad 7$

$3.2 \mathrm{pH} \quad 7$

3.3 Dissolved Oxygen 8

3.4 Electrical Conductivity and Salinity 9

3.5 Turbidity 9

4. Sensors Available for Water Quality Testing 10

$\begin{array}{ll}\text { 4.1 Prototype and Pre-industrial Scale } & 10\end{array}$

4.2 Commercially Available Sensors $\quad 11$

4.2.1 Residual Chlorine Sensor 11

4.2.2 Total Organic Carbon (TOC) Sensor 13

4.2.3 pH Sensors 14

4.2.4 Temperature Sensors $\quad 15$

4.2.5 Turbidity Sensor 16

4.2.6 Ultrasonic Sensor 16

5. Wireless Monitoring Sensor Design 17

5.1 Arduino Mega 18

$\begin{array}{ll}5.2 \text { NodeMCU } & 19\end{array}$

5.3 Thingspeak Server 19

5.4 DHT-11 Sensor 20

6. Future Prospects of Water Quality Assessment 21 
7. Conclusion

References

Appendices

Appendix 1. Title of the Appendix

Appendix 2. Title of the Appendix 
List of Abbreviation

BOD Biochemical oxygen demand

CSIRO Commonwealth scientific and industrial research organization

DO Dissolved oxygen

MIROC Model for interdisciplinary research on climate

ODW Oxygen-demanding waste

PO Pathogenic organisms

TOC Total organic carbon

WQMS Water quality monitoring system

WQT Water-quality testing 


\section{List of Figures and Tables}

Figure 1 Spatial and temporal constraints on water quality evolution

Figure 2 Annual average concentration of ammonium $\mathrm{N}$ measurements

Figure 3 Development of aquatic community and oxygen concentration of the Rhine

Figure 4 Pathogenic sources

Figure 5 A visual presentation of the $\mathrm{pH}$ scale

Figure 6 Sensor construction overview

Figure 7 Photocatalytic mechanism on a semi-conductor surface

Figure 8 PT100 sensor

Figure 9 Block diagram

Figure 10 Diagram of ATmega2560

Figure 11 Diagram of NodeMCU ESP8266

Figure 12 Examples of intelligent water systems

Table $1 \quad$ KaptaTM 3000 OT3 pre-industrialization specifications

Table 2 High risk of the population from water pollution

Table $3 \quad$ Elements of the six scenarios assessed out to 2050. 


\section{Introduction}

Water plays a vital role in the creation of human beings and other natural phenomena. About $80 \%$ of diseases in the developing country are caused by the consumption of polluted water. As we all know, water is not only used for drinking purposes, it has other uses too such as; economic aspects, industrial sites, agriculture, fishing, and other constructive activities. The quality of water is mainly affected by physical, chemical, and biological aspects.

The main sources of water are lakes, rivers, glaciers, groundwater, rainwater, etc. Water is available in every part of the earth whether it is polluted or not. About 80 percent of Earth's land is covered by water. In our day-to-day life water plays one of the most important roles for living beings on earth.[1.] Quality of water is getting very serious attention in our generation. So, to live a healthy and prospective life, checking the water quality is very important.

In the past, water quality has been measured by taking the water samples and sending them to the laboratories, and examining them, which is very costly, time-consuming, and involves more human resources.[2.] This process will not provide real-time data and lead us to the impure quality of water. The proposed water quality monitoring systems consisting of a microcontroller with common sensors are compact and very useful for $\mathrm{pH}$, turbidity, conductivity, water level detection, temperature and humidity of the atmosphere, continuous and real-time data.

This thesis aimed to design the water quality monitoring system using smart sensors, microcontrollers, and wireless systems. Although any definite result was not obtained due to the constraints of the environment, the possibility to get good quality measurement data wirelessly to any system was realized. ATmega2560 and NodeMUC ESP8266 are the components that can build the theoretical water quality monitoring system as discussed in the paper. 


\section{Deterioration of Quality of Water}

Deterioration of quality of water as calculated from three factors mainly(i.e. chemical, physical and biological basis). It occurs every day in the period of supply and consumption of water. The quality of water is very essential for living organisms. Daily human beings drink around two liters of water every day. Around $70 \%$ of the human weight is covered by water. Water covers almost 80 percent of the earth's surface. If we calculate the amount of water available on the earth it is 1,011 million $\mathrm{km} 3$ out of which we can only use $33,400 \mathrm{~km} 3$ of water for drinking, agriculture, domestic and industrial purposes. [3.]

\begin{tabular}{|c|c|c|c|c|c|c|}
\hline \multirow[t]{2}{*}{ Major Causes/Issues } & \multirow[t]{2}{*}{ Major Related Issues? } & \multirow[t]{2}{*}{ Space Scale } & \multicolumn{2}{|c|}{ Time Scale } & \multicolumn{2}{|c|}{ Major Controlling Factors } \\
\hline & & & \multicolumn{2}{|c|}{ Contamination $^{2}$ Clean-up $^{3}$} & Biophysical & Human \\
\hline \multirow[t]{3}{*}{ Population } & Pathogens & Local & $<\mathrm{I} \mathrm{yr}$ & $<1 \mathrm{yr}$ & & Density \& treatment \\
\hline & Eutrophication* & Regional & $<1-10 \mathrm{yr}$ & $1-100 \mathrm{yr}$ & & Treatment \\
\hline & Micro-pollutants & Regional & $<1-10 \mathrm{yr}$. & $1-100 \mathrm{yr}$. & & Various \\
\hline \multirow[t]{3}{*}{ Water Management ${ }^{4}$} & Eutrophication* & Regional & $<1 \mathrm{yr}$ & $10->100 \mathrm{yr}$. & Hydrodynamics & Flow \\
\hline & Salinization & Regional & $10-100 \mathrm{yr}$ & $10->100 \mathrm{yx}$ & & Water Balance \\
\hline & Parasites & Regional & $1-10 \mathrm{yx}$ & $>100 \mathrm{yr}$ & & Hydrology \\
\hline \multirow[t]{5}{*}{ Land Management } & Pesticides & Local-regional & $<1 \mathrm{yr}$ & $1-100 \mathrm{yr}$ & & Agrochemicals \\
\hline & Nutrients $\left(\mathrm{NO}_{3}\right)$ & Local-regional & $10-100 \mathrm{yr}$ & $>10 \mathrm{yx}$ & & Fertilizer \\
\hline & Suspended Solids* & Local-regional & $<1-10 \mathrm{yr}$ & $10-100 \mathrm{yr}$. & & Construction/clearing \\
\hline & Physical Changes & Local & $<1-10 \mathrm{yr}$ & $>100 \mathrm{yr}$ & & Cultivation, Mining \\
\hline & & & & & & Construction \& Clearing \\
\hline \multirow[t]{3}{*}{ Atmospheric Transport } & Acidification* & Regional & $>10 \mathrm{yr}$ & $10 \mathrm{yr}$ & & Cities, melting \& fossil- \\
\hline & Micropollutants & Regional & $>10 \mathrm{yr}$. & $1-100 \mathrm{yr}$ & & fuel emissions \\
\hline & Radionuclides & Regional-global & $<1 \mathrm{yr}$ & $\gg 100 \mathrm{yr}$ & & Industry \\
\hline \multicolumn{7}{|l|}{ Concentrated Pollutant } \\
\hline \multicolumn{7}{|l|}{ Sources: } \\
\hline \multirow[t]{2}{*}{ Mega Cities } & Pathogens & Local & $<1 \mathrm{yx}$. & & & Population \& treatment \\
\hline & Micropollutants & Local-regional & $<\mathrm{I} \mathrm{yr}$ & & & \\
\hline \multirow[t]{2}{*}{ Mines } & Salinization & Local-regional & $10-100 \mathrm{yr}$. & & & Types of mines \\
\hline & Metals & Local-regional & $<1 \mathrm{yr}$ & & & \\
\hline Nuclear Industry & Radionuclides & Local-global & $<1$ yr & & & Waste management \\
\hline Global Climate Change & Salinization & Global & $>10 \mathrm{yr}$ & $>100 \mathrm{yr}$ & $\begin{array}{l}\text { Temperature \& } \\
\text { precipitation }\end{array}$ & $\begin{array}{l}\text { Fossil-fuel cmissions \& } \\
\text { Greenhouse gases }\end{array}$ \\
\hline \multicolumn{7}{|l|}{ Natural Ecological } \\
\hline Conditions & Parasites* & Regional & Permanent & Permanent & Climate \& hydrology & \\
\hline \multicolumn{7}{|l|}{ Natural Geochemical } \\
\hline \multirow[t]{3}{*}{ Conditions } & Salts & Regional & Permanent & Permanent & Climate \& lithology & \\
\hline & Fluoride*4 & Local-regional & & & & \\
\hline & Arsenic**, Metals** & Local-regional & & & Lithology & \\
\hline
\end{tabular}

Figure 1: Spatial and temporal constraints on water quality evolution.[4.]

The above figure 1, its shows that the major causes of water deterioration are population, water management system, land management, rises of industrial sectors, climate changes, and Natural 
geochemical conditions. Figure 1 also mentions space scale, time scale, and what are the major controlling factors. Among those, the factors which have been deteriorating the quality of water have been described below. [4.]

\subsection{Oxygen-demanding Waste}

Water pollutants have been occurring for decades because of oxygen-demanding waste(ODW). The main sources of ODW come from; wastewater from household uses, industrial uses(paper industries, food industries), and wastewater from agriculture.

In the past decades, the growth of industries and agriculture sectors has boomed in the European countries after the 1940s which led to water pollution. On the other hand, the treatment of wastewater management has increased throughout Europe over the past 15 to 30 years.

In the 1970s, the river Rhine was almost dead because of the high use of organic matter. The biochemical oxygen demand (BOD)(which is the measurement of a mixture of organic matters) and ammonia reached pick levels. In 1971, the yearly oxygen concentration was some $5 \mathrm{mg} \mathrm{O} / \mathrm{l}$ and the invertebrate species were extremely low as shown in Figure 2.

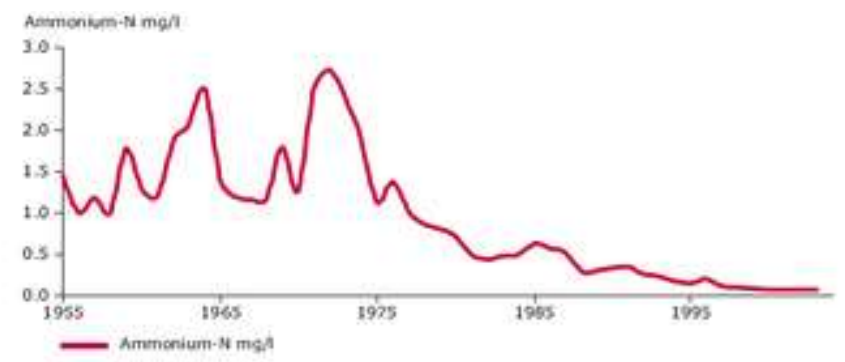

Figure 2: Annual average concentration of ammonium $\mathrm{N}$ measurements at Bimmen/Lobith(Rhine). [5.] 
The progress of biological treatment has been high and the organic waste being controlled over the past 30 years can be seen from figure 3 . In conclusion, the increase of invertebrate species has been high and the organic waste has been low.[4.]

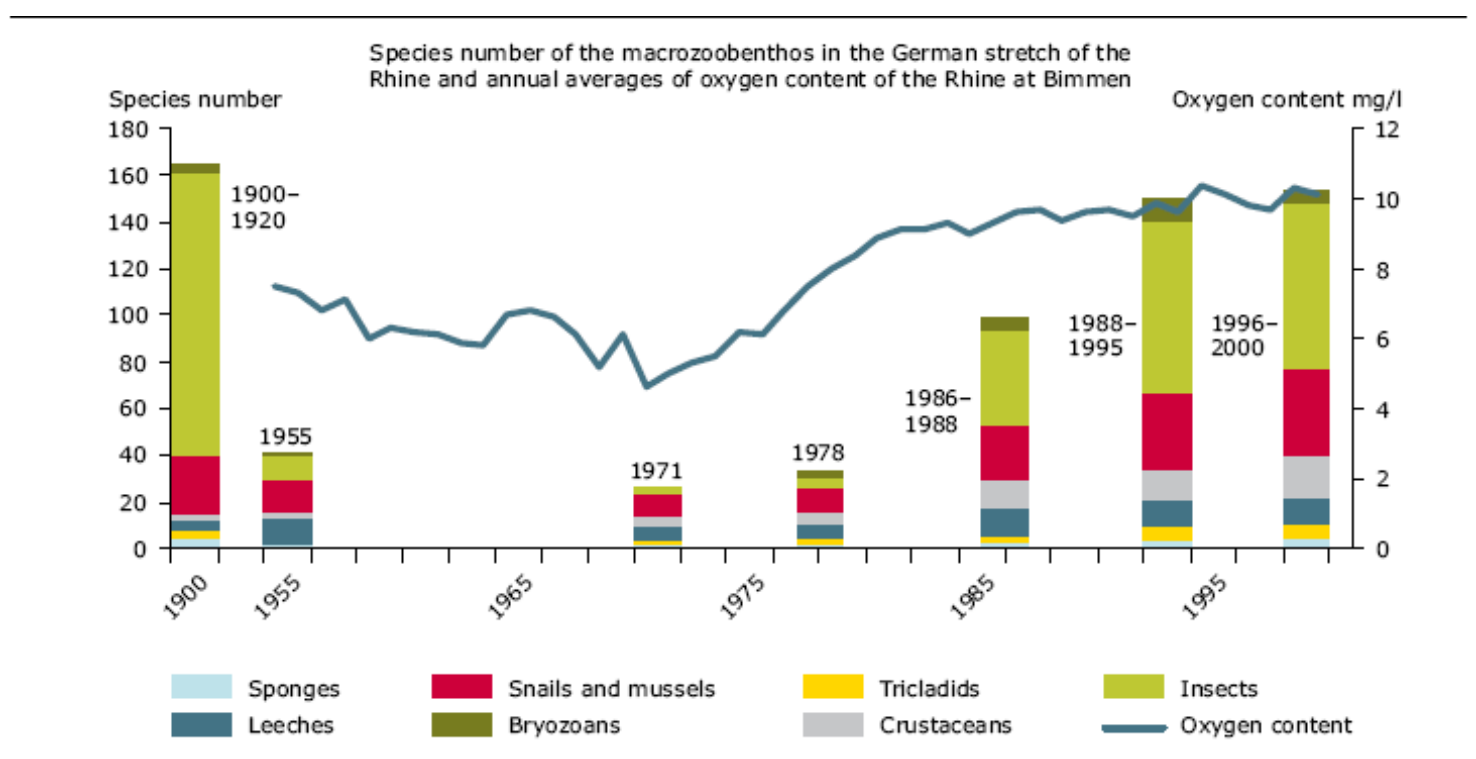

Figure 3: Development of aquatic community and oxygen concentration of the Rhine at Bimmen. [5.]

\subsection{Pathogenic Organisms}

Pathogenic organisms(PO) are water-borne bacteria that have been the major issue for the deterioration of the quality of water. Pathogenic contamination will affect freshwater like; rivers, lakes, groundwater, reservoirs, and saline water resources.

In developing countries like; India, Nepal, Africa, Bangladesh, people will depend on rivers, reservoirs, and lakes to be used for drinking purposes and other household activities. Water pathogens are associated with diseases like diarrhea, gastrointestinal illness, pneumonia, and food allergy. These have been the major issues in these developing countries. People have been using water directly from the rivers which are impure for drinking purposes. [6.] 


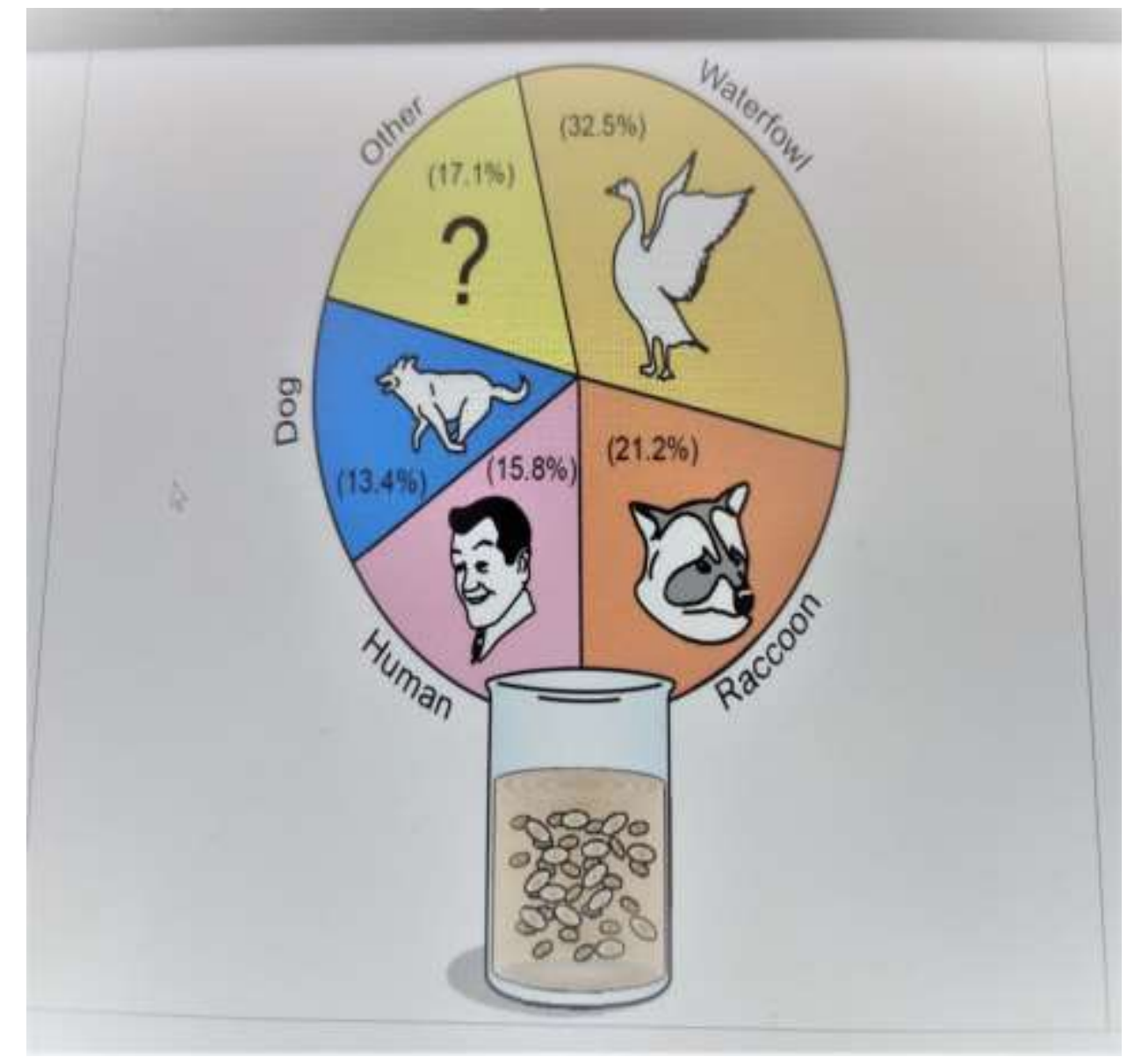

Figure 4: Pathogenic sources.[6.]

The development of pathogenic sources is from human waste, animal waste, waterfowl, and more as shown in figure 4 above. E. coli is the most common transmission bacteria which has been transferred in contact with feces or stool of humans or animals. [6.]

\subsection{Nutrients}

Nutrients are very essential for human beings. The compounds from which we get nutrients are carbohydrates, fats, vitamins, minerals, and water. Water has deteriorated in the process of being realized by human activities. Nitrogen and phosphorus are two main compounds of nutrients. [7.]

In the nitrogen process, it goes through biological and non-biological transformations in the Environment. Inorganic nitrogen occurs in the state of nitrate $\left(\mathrm{No}_{3}{ }^{-}\right)$, nitrite $\left(\mathrm{No}_{2}{ }^{-}\right)$, ammonium ion $\left(\mathrm{NH}_{4}{ }^{+}\right)$, and molecular nitrogen $\left(\mathrm{N}_{2}\right)$. Inorganic nitrogen is converted into organic one from plants 
and microorganisms. In the process of changing, the water has been mixed with chemical substances, fluids, and other unwanted compounds that came from the nitrogen process which occurs in polluting the water. [7.]

\subsection{Oil Spills}

Oil on the shore has been another major issue of getting water deteriorated. Annually around 9 million barrels of oil have been mixed with oceans, lakes, and rivers. From 9 million about half of the oil had been spilled from natural activities like; 35\% from human activities, $12 \%$ from the shipment(tankers, barges, and pipelines), and 3\% from petroleum production.[8.] The water pollution not only fully gets polluted from oil spills but also types of oil, weather conditions, human activities, and organisms exposed in the oceans, rivers, or lakes. [9.] 


\section{Parameters of Water Quality System}

Water quality parameters encompass physical, chemical, and biological values along with monitoring concerns or testing provided samples. Temperature, $\mathrm{pH}$, conductivity and salinity, turbidity, and dissolved oxygen are the frequently applied parameters to obtain water quality. Nevertheless, measuring algae, ISEs (ammonia, nitrate, chloride), and laboratory variables can also be considered as a water monitoring guideline. It is essential to monitor the water quality on open systems if the water is being used for humans or industrial purposes. [10.] Moreover, the description of a few parameters can be found below:

\subsection{Temperature}

The measurement of the average kinetic energy of water molecules on a scale of Fahrenheit or Celsius degrees is referred to as a temperature. It also determines the internal heat or the intensity of heat inside the objects. The kinetic energy results in the movement of the molecules with internal thermal energy. [10.] Thus, it affects the concentration of the dissolved gases and the saturation of the water. To be precise, oxygen amount, rate of photosynthesis by plants inside the water, metabolic rates of aquatic animals are adversely impacted by the increased temperature. The change in the temperature varies with the layers of the water and the duration of the time, i.e, colder at night and warmer at broad daylight. As a result, the temperature is considered an important criterion for water quality. [11.]

\section{$3.2 \mathrm{pH}$}

The measurement of hydrogen-ion $\left(\mathrm{H}^{+}\right)$or negative logarithm of the hydrogen ion concentration is $\mathrm{pH}$ scale. Its value determines the acidity and base of the water where acidic water holds an extra amount of hydrogen ions and base water with extra hydroxyl ions $\left(\mathrm{OH}^{-}\right)$. It is important to have a $\mathrm{pH}$ measurement to determine the state of water, and it is favorable for plants, aquatic animals, or even for drinking purposes. [10.] Figure 5 depicts the visual representation of the $\mathrm{pH}$ value that ranges from 0 to 14 . The lower the value more the water is acidic whereas the pure water has a value of 7.0 and is considered neutral. 


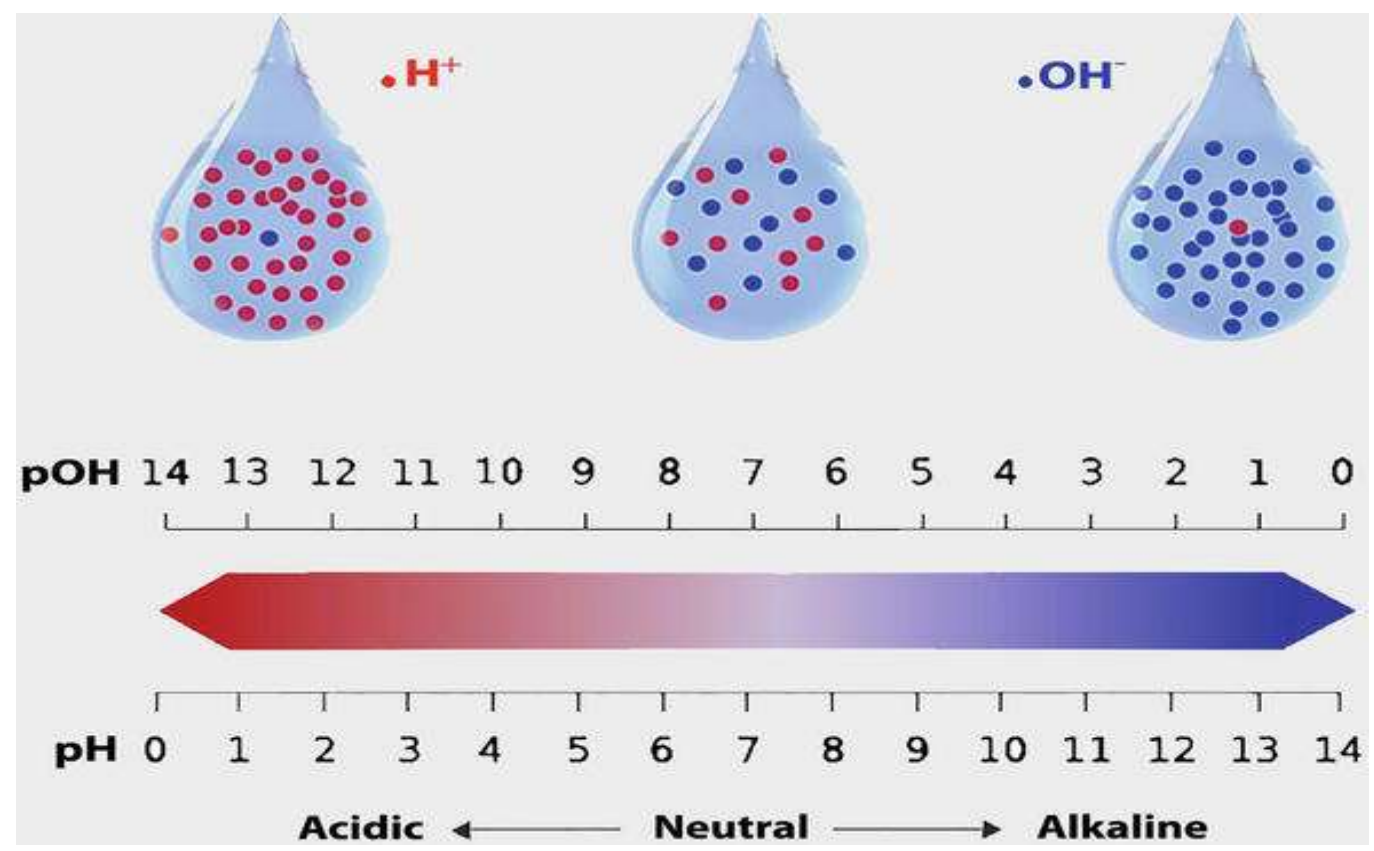

Figure 5: A visual presentation of $\mathrm{pH}$ scale. [12.]

The varying value of $\mathrm{pH}$ can result in several chemical reactions and could affect the lifestyle of aquatic animals since those are adaptive to certain $\mathrm{pH}$ scales. Besides, low $\mathrm{pH}$ can be more deadly to humans as heavy metals can readily dissolve in the water. So, it is important to govern the $\mathrm{pH}$ scale for water quality and is considered as the topmost parameter. [12.]

\subsection{Dissolved Oxygen}

Dissolved oxygen is a basic test of water pollution and one of the important parameters. The water with a higher concentration of oxygen is evaluated as pure water. Although the dissolved oxygen might not have severe consequences on human health, it can bring changes in the taste of water. Atmospheric pressure, temperature, pollution level, the concentration of salt are the several aspects that differentiate the dissolved oxygen (DO) concentration. Due to being a significant parameter, several Sensor technologies are out in the market to measure the concentration of DO. [12.] 


\subsection{Electrical Conductivity and Salinity}

The ability of water to conduct electricity is referred to as electrical conductivity and functions of the types and quantities of dissolved substances in water. Both positive and negative ions present in the water sample are the reason behind the electrical conductivity. This parameter also relates to the number of dissolved solids as it is with ions, i.e. higher the total dissolved solids in the solution, higher the ion concentration, and finally affects the conductivity. [11.]

The amount of salt present in the water or concentration of the dissolved salt in water is salinity. Sodium chloride $(\mathrm{NaCl})$ is generally called a common salt that is present on water bodies along with its ions. Its presence determines the ability for the growth of crops as maximum salinity affects the growth. Salinity is generally measured on PSS or practical salinity scale. [11.]

\subsection{Turbidity}

Turbidity is one of the physical parameters of water quality and is a measurement of the number of suspended particles in the water. The amount of light scattered determines the turbidity of water. The basis to define is solid objects like clay or silt and even algae. The more the water is cloudy, the less it is unhealthy for living organisms. The water treatment could be costly due to this parameter. [11.]

Nephelometric turbidimeter is used for its measurements and value can be represented in NTU or TU. $1 \mathrm{TU}$ is equal to $1 \mathrm{mg} / \mathrm{L}$ of silica in suspension. Most polluted water could have a value up to 100 NTU whereas a lower value of less than 5 NTU is considered normal visibility. Ideally, normal drinking water's value must be below 1 NTU. [11.] 


\section{Sensors Available for Water Quality Testing}

Although many technologies available commercially on the market are used for detecting routine water quality parameters such as free chlorine and TOC, there is a need for further online monitoring systems that can track and record real-time data which is currently not possible with the existing laboratory-based testing methods that are too time-consuming.

Different sensors, both prototype and commercially available will be further explained in detail in this part of the thesis. Since all the data obtained are from manufacturers of these devices, the usability and effectiveness of these technologies will vastly vary depending upon the location and water characteristics. [13.]

\subsection{Prototype and Pre-industrial Scale}

At the forefront of innovation, fluorescence technology has been leading the way for optical sensors that detect dissolved organic matter in polluted water. The United States Geological Survey has used this technology to research sensors for over a decade to develop fluorescence dissolved matter(FDOM) sensors which can provide high-resolution insight into the dissolved organic carbon (DOC) and other biochemicals such as trihalomethane (THM)presurors and methyl mercury (MeHg) concentrations. [13.]

Recently, a pre-industrial scale sensor was developed by SecurEau to monitor water quality, the sensor named KaptaTM 3000 OT3 measures transmission at $254 \mathrm{~nm}$ for organic matter and 625 for turbidity measurements by the use of two light-emitting diodes (LEDs). The use of two wavelengths is to avoid the condition of fouling. In Europe, this sensor is used in two drinking water systems where 40 of these devices measure water quality and send the measurements to the operation center. Some specifications of the KaptaTM 3000 OT3 are detailed in Table 1. 
Table 1. KaptaTM 3000 OT3 pre-industrialisation specifications [13.]

\begin{tabular}{|c|c|c|c|c|c|c|}
\hline Parameter & Range & Resolution & Fidelity & Maintenance & Precision & $\begin{array}{c}\text { Response } \\
\text { time }\end{array}$ \\
\hline $\begin{array}{l}\text { Organic matter } \\
\text { TOC equivalent }\end{array}$ & $\begin{array}{l}0.1-10 \\
\mathrm{mgC} / \mathrm{L}\end{array}$ & $0.1 \mathrm{mgC} / \mathrm{L}$ & $\pm 5 \%$ & \multirow{3}{*}{$\begin{array}{l}\text { The multi- } \\
\text { parameter } \\
\text { probe should } \\
\text { be replaced } \\
\text { every year }\end{array}$} & $\pm 5 \%$ & $<6 s$ \\
\hline $\begin{array}{c}\text { UV absorbance } \\
(254 \mathrm{~nm})\end{array}$ & $\begin{array}{l}0.01-0.3 \\
\mathrm{AU} / \mathrm{cm}\end{array}$ & $0.01 \mathrm{UA} / \mathrm{cm}$ & $\pm 5 \%$ & & $\pm 5 \%$ & $<6 s$ \\
\hline $\begin{array}{l}\text { Turbidity } \\
\text { equivalent }\end{array}$ & $\begin{array}{l}2-50 \\
\text { NTU }\end{array}$ & $1 \mathrm{NTU}$ & $\begin{array}{c}\text { Not } \\
\text { evaluated } \\
\text { yet }\end{array}$ & & $\begin{array}{c}\text { Not } \\
\text { evaluated } \\
\text { yet }\end{array}$ & $<6 s$ \\
\hline
\end{tabular}

\subsection{Commercially Available Sensors}

Sensors readily available on the market are focused on one of the many detection methods, such as residual chlorine sensor, TOC sensor, turbidity sensor, and so on. One sensor from each of the categories will be discussed in detail with the use case and specifications.[13.]

\subsubsection{Residual Chlorine Sensor}

The free chlorine sensor and total chlorine sensor are relentless, electrochemical sensors that continuously measure the chlorine concentration in water. The free chlorine sensor measures the concentration of free chlorine in water generated from inorganic chlorine products, while total chlorine sensors measure the total chlorine i.e free chlorine and combined chlorine in the water. [14.]

Variations in the $\mathrm{pH}$ can affect the accuracy of the sensor, the accuracy can sometimes differ by about $10 \%$ which can be mitigated by the use of an internal temperature sensor. The internal temperature sensor can automatically adjust to compensate for the $\mathrm{pH}$ of the water. [16.] Figure 6 shows one of the free chlorine and total chlorine sensor 


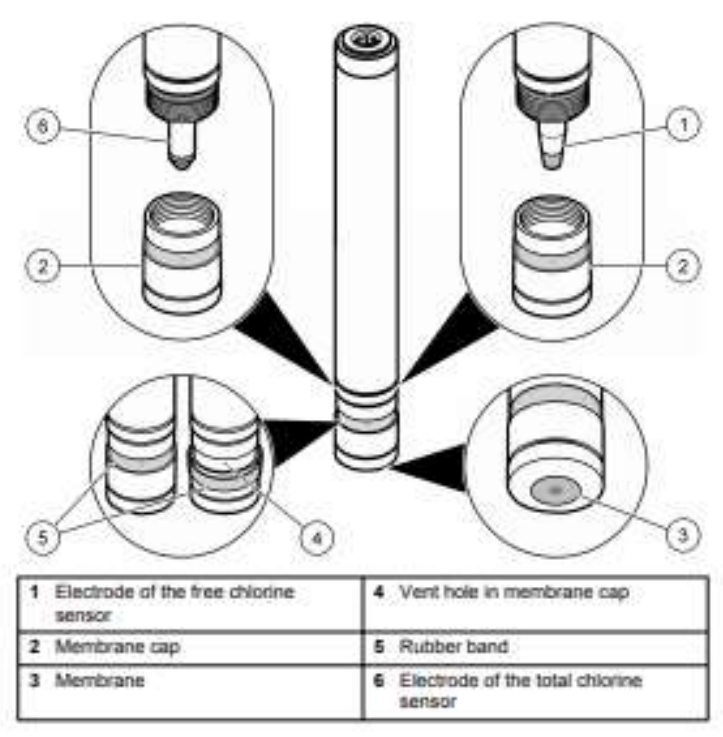

Figure 6: Sensor construction overview[14.]

The sensor in figure 6 is a potentiostatic three-electrode instrument with a specially placed counter electrode. The reference electrode and measuring electrode are both in the electrolyte, while the measuring electrode is covered by a membrane that separates the electrode area from the special electrolyte.

The chlorine concentration is measured by the use of an amperometric method, in which the chlorine species in the sample pass through the membrane and react with the working electrode. This process results in the production of electrical current which is proportional to the chlorine concentration in the sample. Produced electrical current is then amplified by the electronics in the sensor and transmitted in the voltage format $(\mathrm{mV})$. To maintain measurement stability a third electrode is put into the sample and is used to maintain a constant working potential on the working electrode.

$\mathrm{pH}$ fluctuations can cause the measurement to be incorrect so to mitigate the problem a highly buffered electrolyte inside the membrane cap supplies internal compensation which compensates for the inaccuracies. The buffer helps by immediately changing the hypochlorite ions permeating the membrane into hypochlorous acid molecules. Thus, the final readings are independent of either the $\mathrm{pH}$ values or the temperature of the measured water due to the internal compensation. [17.] 


\subsubsection{Total Organic Carbon (TOC) Sensor}

TOC is the measure of organic contamination in the water, which are measured as Carbon molecules, these contaminations are introduced through various processes from purification to distribution which is needed to be measured for TOC to satisfy regulatory requirements. The main objective of the technology involved in the sensor is to completely oxidize the organic matter thus forming carbon dioxide $\left(\mathrm{CO}_{2}\right)$ which can be measured and expressed as the carbon concentration in the sample. The sample might contain organic as well as nonorganic carbon which may be present in the water, these sensors must be able to differentiate between those carbons. One way they discriminate is by deduction of inorganic carbon (IC) from total carbon (TC) which gives the total organic carbon.

TOC $=$ TC - IC

Based on the method of oxidation of organic matter, TOC is differentiated into different types, such as Non-dispersive infrared (NDIR), Direct Conductometric, and Membrane Conductometric Detection. The method of oxidation and detection is what sets one TOC apart from the other.[25]

Photocatalytic sensors are one of the TOC sensors which use light to oxidize organic matter as shown in figure 7. $\mathrm{TiO}_{2}$ is used either alone or with other oxides. $\mathrm{ZnO}$ alone can also be used which gives acceptable outcomes. [16.]

In a photocatalytic mechanism, a semiconductor surface is illuminated with energy greater than 3.1 $\mathrm{eV}(380 \mathrm{~nm})$ to excite the electron which then jumps from the valence band to the conduction band, leaving a positive hole. This electron can be transferred to oxygen or $\mathrm{H++}$, initiating various reactions. The hole can produce hydroxyl radical. Free radicals are strong oxidants that can mineralize organic matter to form carbon dioxide and water in the process as shown in figure 7. [15.]. 


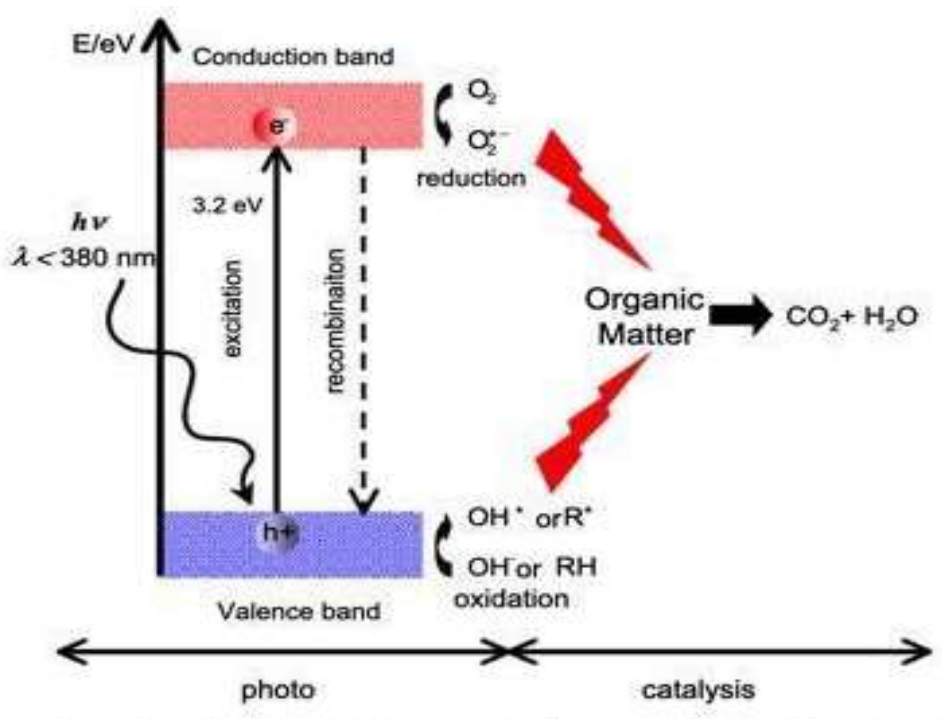

Figure 7: Photocatalytic mechanism on a semiconductor surface, where organic matter is oxidized with the help of strong oxidant radicals. [15.]

\subsection{3 pH Sensors}

The term $\mathrm{pH}$ is derived from " $\mathrm{p}$ ", the mathematical symbol for negative logarithm, and " $\mathrm{H}$ ", the chemical symbol for Hydrogen. It is measured on a scale of 0 to 14 . The $\mathrm{pH}$ value of a substance is directly affected by the ratio of the concentration of hydrogen ion $(\mathrm{H}+)$ and hydroxyl ion $(\mathrm{OH}-)$. $\mathrm{pH}$ testers provide measurable data for the degree of activity of an acid or base in terms of hydrogen ion activity.

Digital $\mathrm{pH}$ meters are used for more accurate $\mathrm{pH}$ measurements, and water quality measurement requires a precise measurement nonetheless. A digital $\mathrm{pH}$ meter consists of three main parts, a pH probe, a reference $\mathrm{pH}$ electrode, and a high input impedance meter. The $\mathrm{pH}$ probe is sensitive to the hydrogen ion, it is a glass bulb with a millivolt output that changes concerning the change in concentration of hydrogen ion inside and outside of the bulb.[17.]

A combination $\mathrm{pH}$ sensor is most widely available and used in the testing of water quality, this is also the case for the reasons that this type of sensor can act as a base for the creation of laboratory sensors and process sensors.[17.] 


\subsubsection{Temperature Sensors}

The temperature of the water plays a vital role in controlling the metabolic, reproductive, and life cycles of aquatic life. The fluctuations in the temperature of the water may disrupt these activities or may cause them to stop completely. These changes in the water temperature are sometimes caused by natural factors such as seasons, the intensity of the sun, and so on. But sometimes the changes are not so natural, humans have used water for many purposes such as electricity generation and cooling agents for massive factories. Therefore, to negate the effects of water temperature fluctuations caused by human activities, water temperature sensors are implemented so the water can be safely released from man-made storage into natural reservoirs such as lakes or rivers. There are various types of temperature sensors such as thermistors, thermocouples, and solid-state temperature sensors which can be used to measure the temperature of the system accurately. [20]

LM35 series sensors are one of the choices in this sensor type. These sensors are accurate integrated circuit temperature sensors whose output voltage is linearly proportional to the temperature of the system. Since the sensor is directly calibrated in Celsius the user does not need to manually calculate the result in centigrade scaling. This sensor is recalibrated as it does not need any external calibration to provide accurate results.

PT100 is a sensor classified under RTD (Resistance Temperature Detectors), these sensors include a resistor that changes the value of resistance with a temperature change. These sensors are used for many years in laboratories and research as the reputation and accuracy of these sensors are very high. The internal circuit diagram of the sensor is shown in the figure below. [21] 

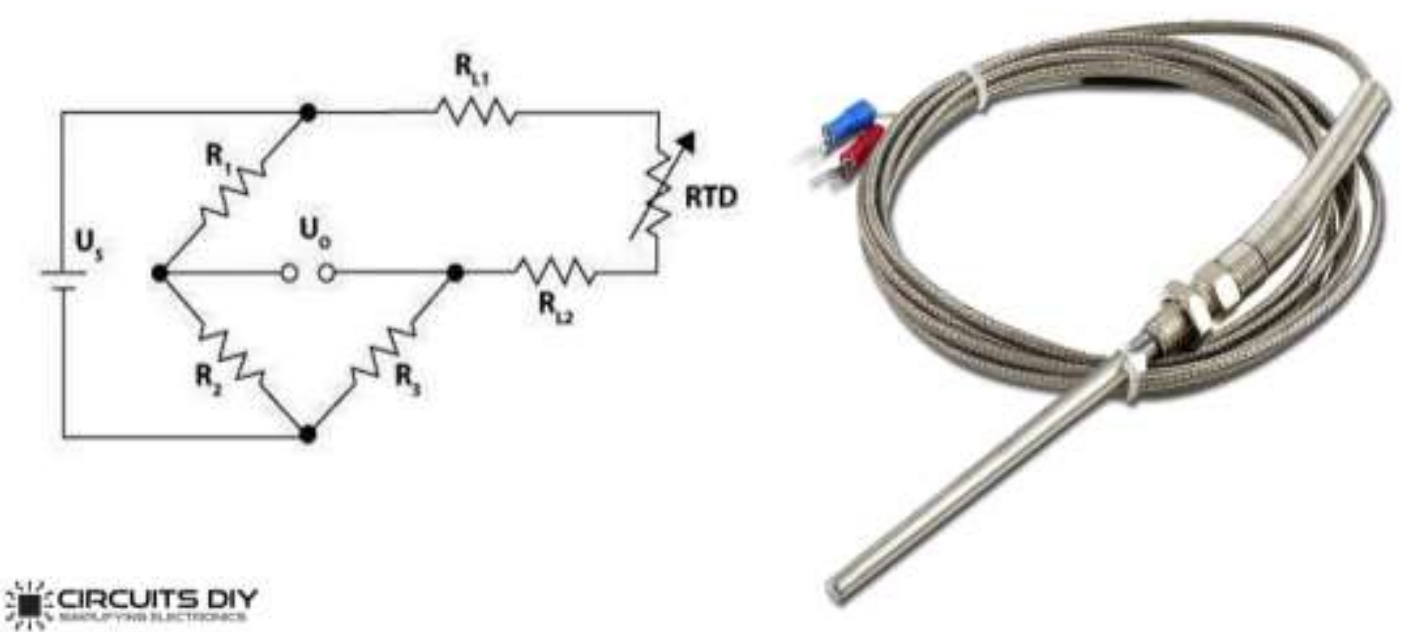

Figure 8: PT100 sensor with 2 wires is commonly used. The sensor consists of a resistance element and insulated copper wires for better protection. The resistance element is usually platinum because of its wide working temperature range. The circuit diagram also further simplifies the inner working of the sensor. [22]

\subsubsection{Turbidity Sensor}

A turbidity sensor is a measurement of the number of suspended particles in the water, the amount of light scattered determines the turbidity of water. For example; sand, plant waste, clay, slit impact the sunlight in the water. If the amount of turbidity is high in water, it will affect marine life as well as human beings too. This sensor works in the $5 \mathrm{~V}$ input voltage with an analog output varying from 0 to $4.5 \mathrm{~V}$. The maximum temperature it will hold is from $100 \mathrm{C}-900 \mathrm{C}$. NTU(Nephelometric Turbidity Units) is the unit of a turbidity sensor.[23.]

\subsubsection{Ultrasonic Sensor}

The HC-SRO4 is the ultrasonic distance sensor, which is available economically. It has contactless calculation functionality varying from $2 \mathrm{~cm}$ to $400 \mathrm{~cm}$. This sensor has four pins; VCC(power), trigger, echo(receive), and ground. The accuracy of this sensor ranges up to $3 \mathrm{~mm}$.[27.] 


\section{Wireless Monitoring Sensor Design}

In this thesis, different types of sensors were researched to achieve the precise measurement of the water quality parameters as mentioned above. $\mathrm{pH}$, turbidity, ultrasonic, and DHT-11 are the four sensors used for the proposed system, whereas the microcontroller unit and ESP8266 wi-Fi module(NodeMCU) are used for the main processing unit and one data transmission module. The main part of this system development for water quality measurement is the microcontroller unit. Arduino Mega has been used for a microcontroller unit that consumes low power and its small size, which is effective for sale technology criteria too.

The four sensors can be used to collect the data, out of four sensors, two of them were used to collect data in the form of analog signals where the MCU has an on-chip ADC which translates the analog signals into the digital form, these two sensors will be connected to the MCU's analog pins, whereas other two sensors will be connected to the MCU units of the digital pins. All the data will be recorded and processed to the Thingspeaker server with the help of the Wi-Fi data communication module ESP8266(NodeMCU) to the main server. The block diagram of the prospects for water quality measurement is shown in Figure 9.

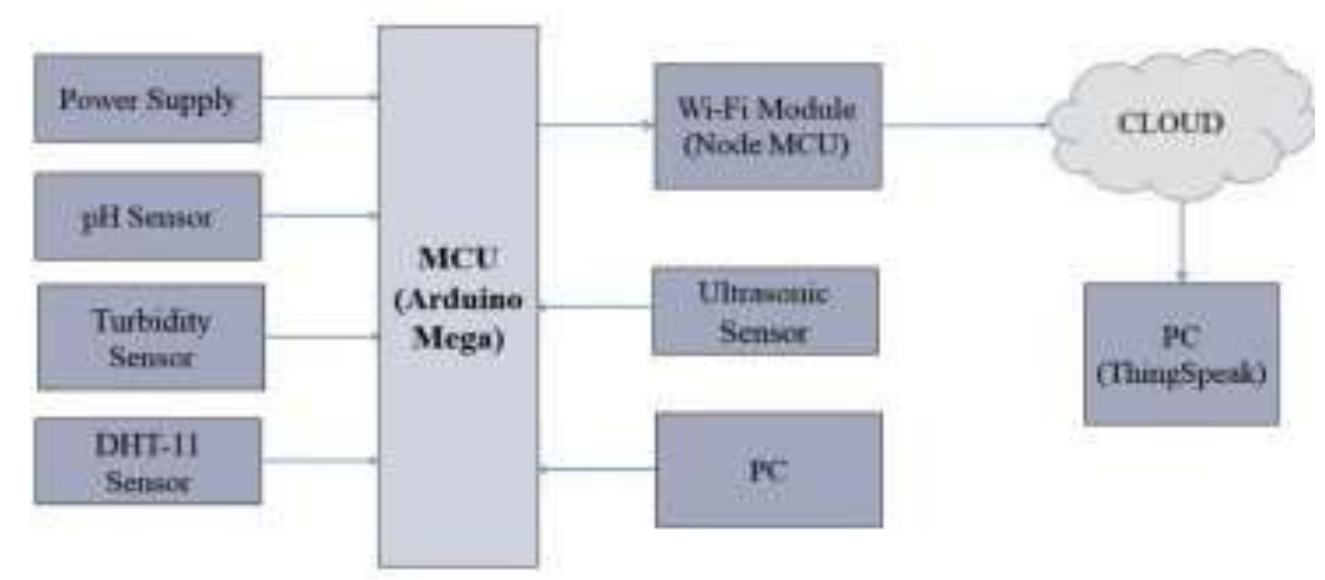

Figure 9. Block diagram

The water quality monitoring system uses sensors to collect data on $\mathrm{pH}$, turbidity, level of water, temperature, and humidity. Arduino Mega and NodeMCU are the boards that can be used in the proposed Future system.[23.] 


\subsection{Arduino Mega}

It is a microcontroller board based on the ATmega2560. It consists of 54 digital input/output pins from which 15 can be used as PWM outputs. Moreover, it has 16 analog inputs, 4 UARTs, a 16 $\mathrm{MHz}$ crystal oscillator, a USB connection, a power jack, an ICSP header, and a reset button as shown in figure 10. This board is compatible and easily connects to a computer with a USB cable. It can be powered with a USB connection or with an external power supply (which can come from either AC to DC adapter or battery). An external supply of 6 to 20 volts can operate this board but the recommended range is 7 to 12 volts. The Arduino Mega2560 formally called an Arduino Mega without the '2560' extension because it was the replacement of the old Arduino Mega. Arduino mega is frequently found in complex projects like Radon detectors, 3D printers, temperature sensing, loT applications, real-time data monitoring applications, etc. As shown in figure 10, the circuit diagram of ATmega2560, has an analog comparator, external interrupt and software interrupt, power saving mode, inbuilt temperature sensor, RTC, and many more features.[24.]

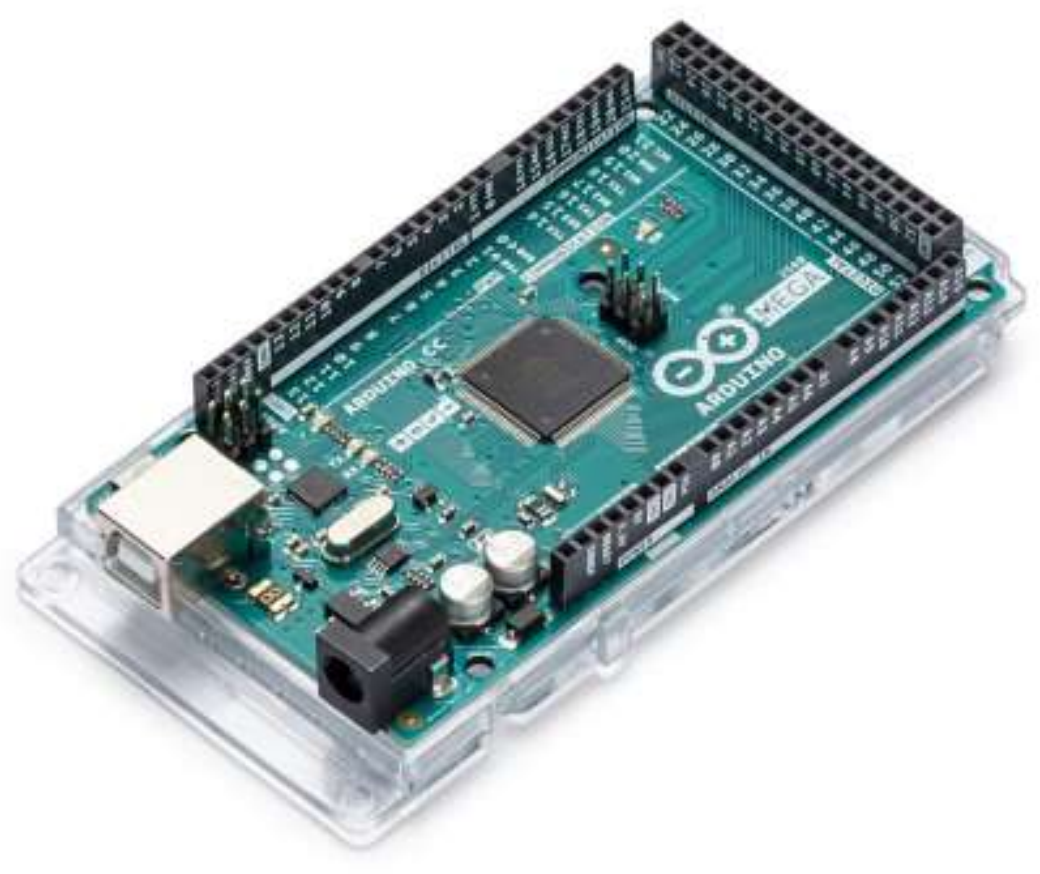

Figure 10. Diagram of ATmega2560 [24.] 


\subsection{NodeMCU}

NodeMCU is an open-source firmware for loT platforms, it consists of Espressif systems ESP8266 Wi-Fi chip and ESP-12 module-based hardware. The power supply can easily be done through the USB port. It is used to measure analog voltage in the range of $0-3.3 \mathrm{~V}$, and it has 16 general purpose input-output pins on its board of which four pins are available for serial peripheral interface(SPI) communication. NodeMCU has two UART interfaces, UART0(RXD0 \& TXD0) and UART1(RXD1 \& TXD1) as shown in figure 11. UART1 is used to upload the program. NodeMCU is a small-sized module that will fit smartly inside our projects. It supports RTOS and operates at $80 \mathrm{MHz}$ to $160 \mathrm{MHz}$ adjustable clock frequency. To store data and programs it has $128 \mathrm{~KB}$ RAM and 4MB of flash memory. It is ideal for IoT projects because of its high processing power with Wi-Fi/Bluetooth and deep sleep operating features.[25.]

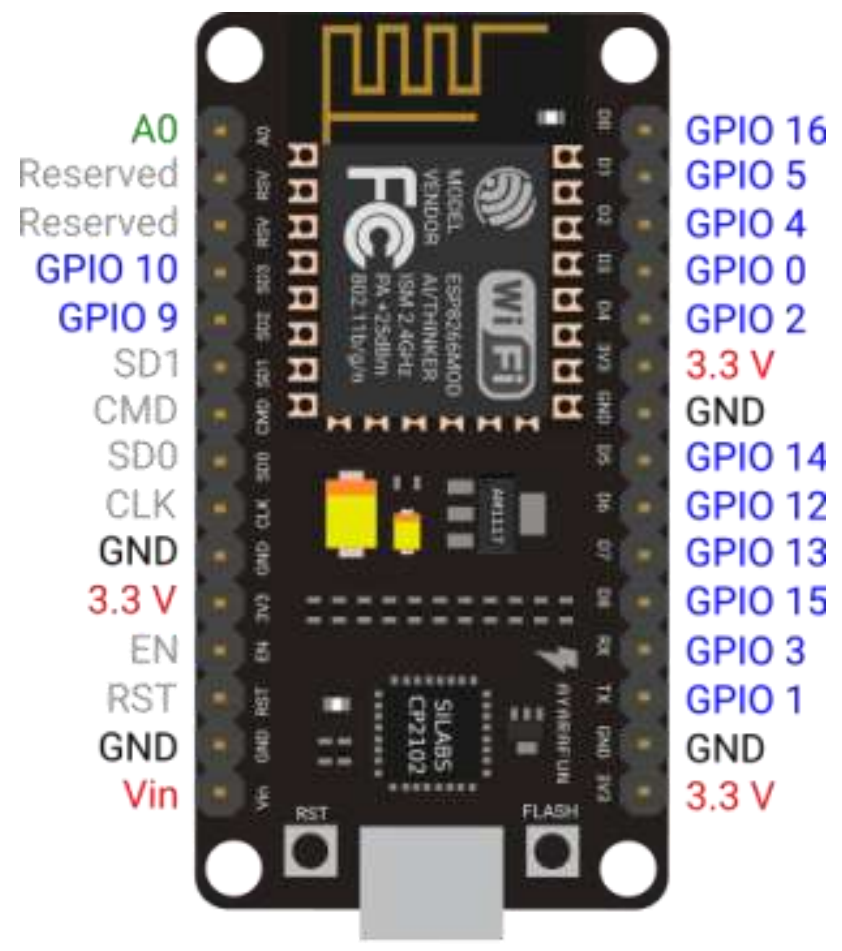

Figure 11. Diagram of NodeMCU ESP8266[25.]

\subsection{Thingspeak Server}

Thingspeak is the application that is used to collect data from various sensors, like; temperature, $\mathrm{pH}$, turbidity, moisture, distance, etc. It is an IOT application, to use this server the user needs to log in first. The data collector will collect the data and send it to the Wi-Fi module(NodeMCU 
ESP8266) after that the data will be sent to the Thingspeak server and the data will be modified and processed into MATLAB code and the data will be reacted by some alerts sound.[23.]

\subsection{DHT-11 Sensor}

The sensor is used to calculate the temperature and humidity values of the encompassing atmosphere. The operating voltages of this sensor range from $3.5 \mathrm{~V}$ to $5.5 \mathrm{~V}$ and the operating current is $0.3 \mathrm{~mA}$ (measuring), it gives the output in serial data both for temperature and humidity. The temperature and humidity range of this sensor are from $0 \mathrm{C}$ to $50 \mathrm{C}$ and $20 \%$ to $90 \%$. The accuracy levels of this sensor are $\pm 1 \mathrm{C}$ and $\pm 1 \%$.[26.] 


\section{Future Prospects of Water Quality Assessment}

Water Quality has been a major issue in the world, especially in developing countries because of the shortage of technical manpower for operation and maintenance. Due to the rise of population in Asia, river water quality has deteriorated due to human activities, climate change, petroleum products, inorganics substances, and biochemical oxygen demand(BOD).

CSIRO-Mk3.0 and MICRO 3.2 are two general circulation models which have been used for climate change projection. The CSIRO models estimated the drier climate whereas, on the other hand, MICRO estimated the wetter climate by 2050. 1 out of 8 people are at big risk of water pollution from BOD, 1 out of 6 people are at risk from nitrogen pollution and 1 out of 4 people are at a risk from phosphorus pollution. These cases mostly affect people who stay in developing countries in Asia by 2050 as shown in the table 2.[18.]

Table 2: High risk of the population from Water Pollution[18.]

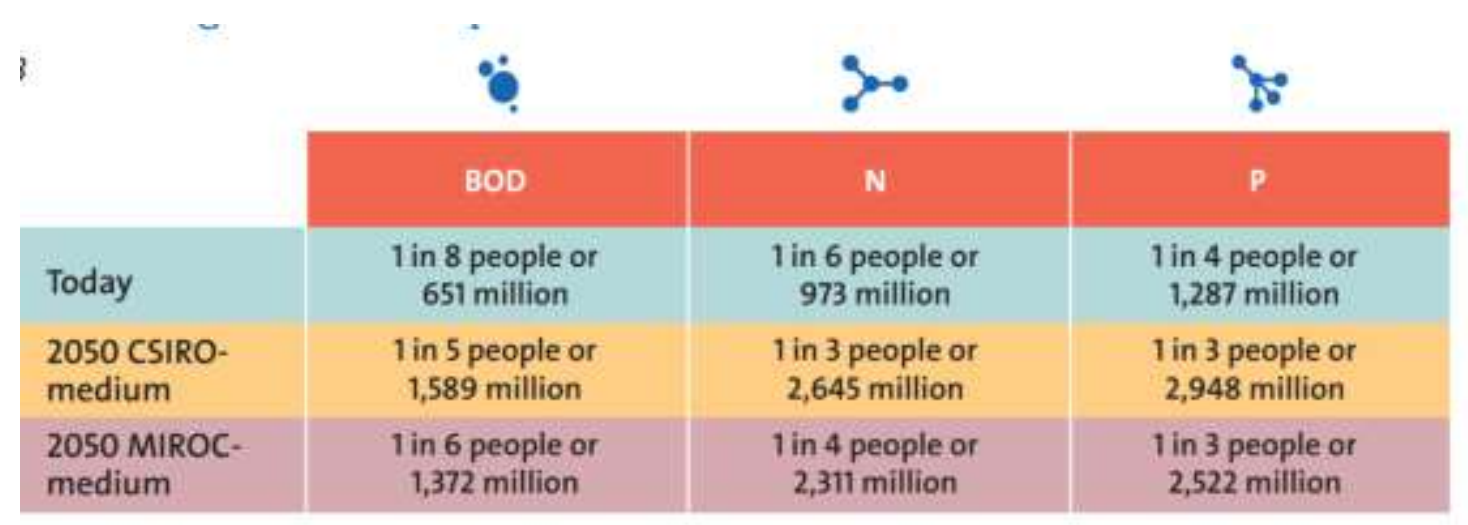

we can achieve a greener world, reduce water pollution and support the Sustainable Development Goals. The optimistic scenario need simplified municipal wastewater cure, improvements in nutrient use efficiency, slower population growth and rapid growth in the global economy. Under the "optimistic" scenario, the rate of municipal wastewater cure will rise by $30 \%$ over the base period, and nutrient use efficiency (NUE) in crop production (expressed in $\mathrm{kg}$ crop yield per kg nutrients applied) is assumed to improve by $40 \%$ (except for the least developed countries). With medium population and GDP growth, the presumed rate of increase in municipal wastewater cure is $15 \%$ and the NUE improvement is only $20 \%$. No changes in the municipal wastewater cure rate and 
NUE are presumed under pessimistic predictions. Under the drier future projected by the CSIRO global circulation model, global crop harvested area expands by $15-18 \%$, and livestock numbers increase by $14-28 \%$. The expected growth rates of crop harvested area and animal counts under the wetter MIROC model range from $17-21 \%$ and $16-27 \%$, respectively as shown in table 3.[18.]

Table 3: Elements of the six scenarios assessed out to 2050.[18.]

\begin{tabular}{|c|c|c|c|c|c|c|}
\hline & $\begin{array}{l}\text { csieg } \\
\text { medium }\end{array}$ & $\begin{array}{c}\text { CSine } \\
\text { optimistic }\end{array}$ & $\begin{array}{c}\text { C्Sino } \\
\text { pessimitatic }\end{array}$ & $\begin{array}{l}\text { Miroc: } \\
\text { medium }\end{array}$ & $\begin{array}{l}\text { MuROC } \\
\text { optimintic. }\end{array}$ & $\begin{array}{c}\text { Muipoc } \\
\text { pessimistic }\end{array}$ \\
\hline Population in 2050 & 9.3 billion & 8.1 billion & 10.6 billion & 9.3 billion & 8.1 billion & 10.6 billion \\
\hline Annual, average rate of GDP growth & $32 \%$ & $3.6 \%$ & $19 \%$ & 3.28 & $3.6 \%$ & $19 \%$ \\
\hline Crop harvest area & $+175 \%$ & $+14.7 x$ & $18.4 \%$ & $+2000 x$ & $+17.2 \%$ & $20.9 \%$ \\
\hline $\begin{array}{l}\text { Nutrient use efficiency } \\
\text { (expressed in crop yield (tag) per kg nutrieat applied) }\end{array}$ & $+20 \%$ & $+40 \%$ & No change & $+20 \%$ & $+40 \%$ & No change \\
\hline Livestock numbers & $+26 x$ & +288 & $+14 \%$ & $-25 \%$ & $\cdot 27 \%$ & •16\% \\
\hline $\begin{array}{l}\text { Improvement in municipal wastewater } \\
\text { treatment levels }\end{array}$ & $+15 \%$ & $+30 \%$ & No change & $+15 \%$ & +308 & No change \\
\hline
\end{tabular}

For example; In Japan, a company named Hitachi sticks to the concept of an intelligent water system in 2010, presenting the key approach to acquiring the best results from management of water resources and infrastructure at the city or catchment level. At the end of 2015, Japan had $97.9 \%$ reportage for water supply and $77.8 \%$ for sewerage services. The main issues behind the improvement of aging infrastructure, which was built in the 1960s and 70s.

It is predicted that elements such as sensors and the telecommunication and the process of regional coordination of water supply and sewerage services in Japan will increase in the future for the request of things like remote monitoring of equipment, regional management, and the centralized administration of information as shown in figure 12.[19.] 


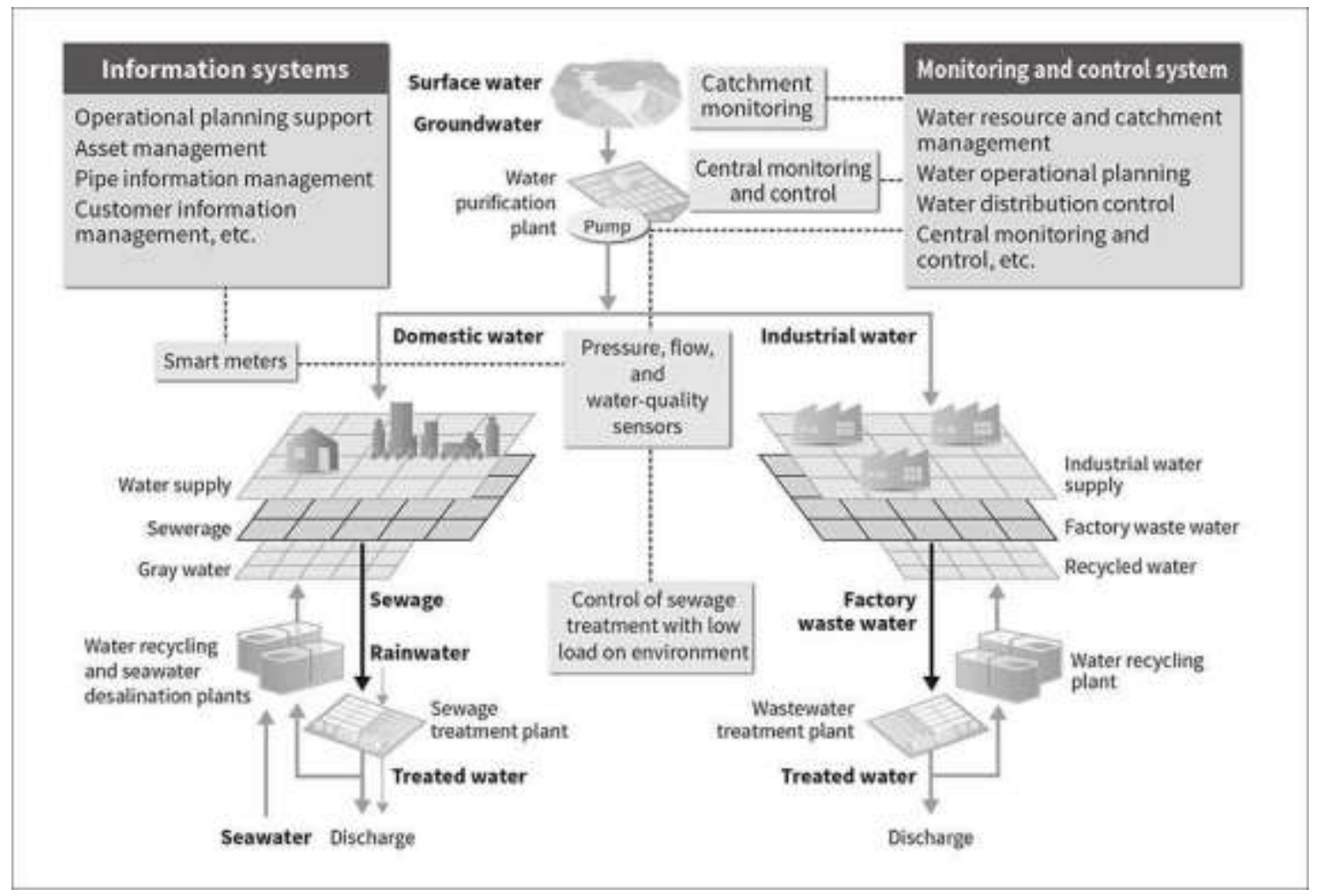

Figure 12: Examples of Intelligent water systems [19.]

This idea helps improve the distribution of water throughout a city or region through the wide-area integration of water management and treatment systems with information and control systems. This is a idea of thinking about how to implement IT and control technologies at a regional level to acquire goals such as improved reliability, more systematic regional management, and lowered load on the environment as shown in figure 12.[19.] 


\section{Conclusion}

This thesis has provided an overview of the water quality monitoring system(WQMS), which includes how water has deteriorated, parameters of WQMS, sensors available for WQT, and prospects of WQT mainly focus on developing countries. The scarcity of quality water is increasing day by day in developing countries. In this thesis, the parameters for water quality degradation such as temperature, $\mathrm{pH}$, turbidity, and conductivity are also explained in detail. It also shows how the water quality assessment technology will be developed in the future, and their implementation to control the dire need of water scarcity will be resolved.

The goal of this thesis was to design the water quality monitoring system using smart sensors, microcontrollers, and wireless systems. Although any definite result was not obtained due to the constraints of the environment, the possibility to get good quality measurement data wirelessly to any system was realized. ATmega2560 and NodeMUC ESP8266 are the components that can be used to build the theoretical water quality monitoring system as discussed in the paper.

The future of water quality does not look better as the development and industrialization of the developing countries have just begun. Although, if the precautions are applied soon and the systems placed at the right time then it can be prevented well in developing countries. If the designs explored in the paper were to be implemented in the future then the need for human intervention would be minimal and there will be more chances of getting good quality water in developing countries. 


\section{References}

1. Abbaspour Somaya. Water Quality In Developing Countries, South Asia, South Africa, Water Quality Management and Activities that cause Water Pollution. 2011 [online].

URL: http://ipcbee.com/vol15/17-U10016.pdf

Accessed out 27 December

2. Wahab Bahiyah Abdul Nur, Mohd Fauzi Mohd Yunus and Sharifad Nurulhuda Tuan Mohd Yasin. The Development of water quality monitoring system using Internet of Things. March 2020.

URL:https://www.researchgate.net/publication/340894428_The_development_of_water_quality_ monitoring_system_using_internet_of_things

Accessed 2 January 2021

3. STUDYDRIVER. Deterioration Of Quality Of Water [Online].

URL: https://studydriver.com/deterioration-of-quality-of-water/

Accessed 10 January 2021

4. Dr. Peters E. (Jake) Norman and Dr. Meybeck Michel. Water Quality Degradation Effects on Freshwater Availability: Impacts of Human Activities [Online]. June 2000.

URL:https://www.researchgate.net/publication/237332027 Water Quality Degradation Effects on Freshwater Availability Impacts of Human Activities

Accessed 13 January 2021

5. European Environment Agency. Water Quality And Pollution By Oxygen Consuming Substances[online]. 24 June 2020

URL:https://www.eea.europa.eu/archived/archived-content-water-topic/status-andmonitoring/state-of-surface-waters/water-quality-and-pollution-by-oxygen

Accessed 15 January 2021 
6. Pandey k. Pramod, Biswas Sagor, Soupir L Michelle, and Kass H Philip. Contamination of Water resources by Pathogenic bacteria[online]. June 2014.

URL:https://www.researchgate.net/publication/263779119 Contamination of water resources b y pathogenic bacteria

Accessed 17 January 2021

7. Chapman Deborah. Water Quality Assessments - A Guide to Use of Biota, Sediments, and Water in Environmental Monitoring-Second Edition[Online]. 1996

URL:https://apps.who.int/iris/bitstream/handle/10665/41850/0419216006 eng.pdf ?sequence $=1 \& \mathrm{i}$ sAllowed=y\&fbclid=IwAR0XZW7sjyrZ2K3cKV61A7AomAkqVu2AG6mz9mdVGohQEVDzk0T0 G ZYk2U

Accessed 21 January 2021

8. Cohen M.A. Water Pollution From Oil Spills[online].

URL:https://www.sciencedirect.com/science/article/pii/B9780123750679000942?via=ihub

Accessed 24 January 2021

9. Ewida Ayman. Oil Spills: Impact on Water Quality and Microbial Community of the Nile River, Egypt[online]. December 2015

URL:https://www.researchgate.net/publication/314151285 Oil spills Impact on Water Quality and Microbial Community of the Nile River Egypt

Accessed 27 January 2021

10. Azzuni Abdelrahman. DESIGN, IMPLEMENTATION, AND EVALUATION OF AN ONLINE WATER QUALITY MONITORING SYSTEM IN LAKE SAIMAA, FINLAND[online]. December 2014

URL:https://www.researchgate.net/publication/277669396 DESIGN IMPLEMENTATION AND EVALUATION OF AN ONLINE WATER QUALITY MONITORING SYSTEM IN LAKE SAIM AA FINLAND

Accessed 7 February 2021

11. Waterboard. Vital Signs: The Five Basic Water Quality Parameters[online]. 
URL:https://www.waterboards.ca.gov/water issues/programs/swamp/docs/cwt/guidance/310.pdf ?fbclid=IwAR24NaLxmTGKxDNw bo1CN2A9Pw7kvOISJ2vtCdrDtbu2hV rBZ3iE--I5U

Accessed 10 February 2021

12. Omer Hassan Nayla. Water Quality Parameters[online]. 16 October 2019

URL:https://www.intechopen.com/books/water-quality-science-assessments-and-policy/waterquality-

parameters?fbclid=IwAR1CsTTIwaliPuAfF60ISp8LV Dqn9R3JCnhVkUHvkeLWDH2dQE2IPGtO $\underline{\mathrm{CU}}$

Accessed 13 February 2021

13. Raich Jordi. Review Sensors to monitor water quality. 2013.

Monitor water quality, EUR 26325 EN(2013), 9-10.

URL:https://erncipproject.jrc.ec.europa.eu/sites/default/files/Review of sensors to monitor wate $r$ quality.pdf

Accessed 1 March 2021

14. Burket Fluid Control Systems. Chlorine Sensor[online].

URL:https://cms.esi.info/Media/documents/9639 1505990820008.pdf

Accessed 4 March 2021

15. Namour Philippe, and Renault-Jaffrezic Nicole. Sensors for measuring biodegradable and total organic matter in water. September 2010.[online]

URL:https://www.researchgate.net/publication/222676880 Sensors for measuring biodegradabl $\mathrm{e}$ and total organic matter in water

Accessed 10 march 2021

16. EDINBURGH SENSORS. TOTAL ORGANIC CARBON.[Online]

URL: https://edinburghsensors.com/industries/total-organic-carbon-toc/

Accessed 15 march 2021 
17. OMEGA. A Spectris Company. pH meter.[online]

URL: https://www.omega.co.uk/prodinfo/pH-meter.html

Accessed 20 march 2021

18. INTERNATIONAL FOOD POLICY RESEARCH INSTITUTE(IFPRI). The Murky Future of Global Water Quality.[online]

URL:http://ebrary.ifpri.org/utils/getfile/collection/p15738coll2/id/129349/filename/129560.pdf

Accessed 02 April 2021

19. Tachi Takahiro, Okuno Yutaka, Takemoto Takeshi, Suzuki Tomoko, and Onishi Makoto. Overview of Water Environment Solutions and Future Prospects.[online.]

URL:https://www.hitachi.com/rev/archive/2017/r2017 07/r7-01/index.html

Accessed 10 April 2021

20. Patil Kiran, Patil Sachin, Patil Sanjay and Patil Vikas. INTERNATIONAL JOURNAL FOR RESEARCH IN EMERGING SCIENCE AND TECHNOLOGY, VOLUME-2, ISSUE-3, MARCH2015. MONITORING OF TURBIDITY, PH, AND TEMPERATURE OF WATER-BASED ON GSM.[online]

URL:https://ijrest.net/downloads/volume-2/issue-3/pid-ijrest-23201508.pdf

Accessed 13 April 2021

21. Nair Lakshmi, Malekian Reza, Cloete Andre Niel. Design of Smart Sensors For Real-time water Quality Monitoring. January 2016[online].

URL: (PDF) Design of Smart Sensors for Real-Time Water Quality Monitoring

Accessed 16 April 2021

22. What is an RTD Temperature Sensor? Working \& Application[online].

URL: https://circuits-diy.com/amp/what-is-an-rtd-temperature-sensor-working-application/

Accessed 17 April 2021 
23. Pasika Sathish and Gandla Teja Sai. Heliyon. Volume 6, Issue 7, July 2020, e04096. Smart water quality monitoring system with cost-effective using IOT[online].

URL:https://www.sciencedirect.com/science/article/pii/S2405844020309403\#fd1

Accessed 19 April 2021

24. ARDUINO.CC. Arduino Mega 2560[online].

URL:https://store.arduino.cc/arduino-mega-2560-rev3

Accessed 20 April 2021

25. NodeMCU ESP8266 [online].

URL:https://components101.com/development-boards/nodemcu-esp8266-pinout-features-anddatasheet

Accessed 20 April 2021

26. DHT11- Temperature and Humidity Sensor[online].

URL: https://components101.com/sensors/dht11-temperature-sensor

Accessed 21 April 2021

27 Ultrasonic Distance Sensor; HC-SRO4[online].

URL: https://www.sparkfun.com/products/15569

Accessed 21 April 2021 
Appendix 2

1 (1) 